NATALIA KŁYSZ-SOKALSKA

Uniwersytet im. Adama Mickiewicza

$w$ Poznaniu

\title{
MUSIC EDUCATION AS A KEY FACTOR IN THE FULL DEVELOPMENT OF A CHILD ${ }^{1}$
}

\begin{abstract}
Kłysz-Sokalska Natalia, Music Education as a Key Factor in the Full Development of a Child [Edukacja muzyczna jako kluczowy czynnik rozwoju dziecka]. Studia Edukacyjne nr 42, 2016, Poznań 2016, pp. 263-272. Adam Mickiewicz University Press. ISSN 1233-6688. DOI: $10.14746 /$ se.2016.42.16
\end{abstract}

Music education is a field of pedagogy dedicated to the development of the individual through artistic action, which is manifested in various forms and activities. Properly conducted music education has a beneficial effect on the right development of child. Research shows that music education stimulates the competence of child's language and mathematical skills, affect the development of creative child's personality and its socialization. Neurodidactics points to the significance of playing the instruments to neurogenesis and the development of skills of concentration, memory and attention. Movement to music, however, is developing spatial and mobility coordination, involves sight and hearing, which has a beneficial effect on the mastery of the whole body - muscles and nervous system.

Unfortunately, despite the enormity of the positive aspects, music education is treated superficially, which shows a small amount of hours music lessons at school and inadequate preparation and attitude of teachers for music education. The difficulty with which collides every day music education is also a contemporary musical culture. The low level of the presented music content being the only "marketing product" makes that music education becoming too elitist activity, or is forced to follow along with system.

Key words: music education, music teacher, music and development of child, music education and pop-culture

Music education, also known as education through music or musical training, is a field dedicated to the development of an individual through

1 This article were published in Polish in the book: N. Kłysz-Sokalska, Edukacja muzyczna kluczem do petnego rozwoju dziecka, [in:] Edukacja na rozdrożu. Część 3 - Dzieciństwo szans i zagro$\dot{z} e n ́$, ed. R. Bernatova, S. Kania, S. Śliwa, Wydawnictwo Instytut Śląski, Opole 2016, p. 156-163. 
artistic activity. This process manifests itself in various forms and activities such as singing, playing instruments, movement with background music, dancing, creating music, improvisation, music perception, as well as the correlation of music and other fields of art or science. The versatility of techniques and methods available for selection allows the full development of an individual along with creating the possibility of meeting the needs of anyone this type of education concerns.

The problem of contemporary music education in Poland is the strikingly superficial treatment of this field of pedagogy. One hour of musical education in a weekly lesson system in primary schools, high flexibility in the implementation of such classes in junior high school and complete elimination of it in high school leads to reducing the cultural and aesthetic development of students. The system which so strongly limits the musical education, fails to provide the students and the teachers with a chance for educational activities of music as the link and as the foundation of education. The impact of musical activities on other aspects of human cognitive sphere has been examined repeatedly. The results indicated a strong interaction and correlation between music and other arts and sciences. The reference to these results through the implementation of specific concept of systemic changes would be an opportunity for the full development of young people.

\section{Pedagogy of music in pop-culture}

Analyzing the overall ease of access to music, we can say that the development of a child based on the pedagogy of music should be equally simple. Unfortunately, there is no question of any development, since the contemporary popular and widely available music does not give the student anything, except for a short-term feeling of pleasure. The diversity of channels and music services on television and the Internet provides a simple way of obtaining new Music Products. The use of the term "products" is not accidental. Currently, music is one of the parts of commerce, business and profit. Its egalitarianism is determined by the largest music industries. Access to popular music is broad and simple, its reception does not require higher levels of perception. According to Wieslawa Sacher, ${ }^{2}$ music often acts as a servant to other arts and various social phenomena, sometimes of a ludic or marketing kind.

${ }^{2}$ W.A. Sacher, Pedagogika muzyki. Teoretyczne podstawy powszechnego ksztatcenia muzycznego, Kraków 2012, p. 11. 
It is interesting that besides music educators, also the media notice the problem of the level of contemporary popular music. Robert Sankowski, a journalist who writes for "Gazeta Wyborcza", in his article Polska krajem muzycznego obciachu. Co sie stało z naszym popem? ${ }^{3}$ comments on the low format presented by the contemporary popular music in Poland. The author begins his discussion with an observation that the star status is more and more quickly given to any new "artist". "The title of the star is no longer reserved for an outstanding performer, having the great hits or even remarkably popular". According to Sankowski, anyone can become a star if they present their artistic achievements to the wider audience, are recognizable and can be called a "celebrity". The author "accuses" the media of the state of Polish music. Television and radio seem to promote "mass production on the borderline of marketing, not artistic events". Sankowski also refers to the problem of easy access to live music in free concerts of artists most popular on the radio and on the Internet. According to the author, free musical performances "accustomed the audience to the fact that the concert is an event for which they do not have to pay, and that it may actually be merely an addition to the broader entertainment". Another point which, according to Sankowski affects the level of Polish musical culture, is the lack of adequate legal regulations affecting the quality of the presented artistic forms and state institutions supporting the development of Polish popular music. The author notes that the problem of low-quality musical culture affects not only Poland, but also other European countries. The awareness of this dilemma affects the positive changes in countries such as the UK, France, Sweden, Norway, while Poland remains in the state of a stagnant musical mediocrity. Music critics, radio presenters, music journalists, as well as music educators note, that the problem of the low level of Polish music can stem from absurd insecurities of Polish artists. Absurd, because if we analyzed Polish musical culture over the ages, we would notice its rapid development, many changes of musical forms and genres, and often innovative approach to music. Moreover, the Polish folk music prides itself on its uniqueness and originality. Frequent references of great composers to the typically Polish rhythm, melody, harmony and instrumentation defined the Polish musical culture and made it stand out from other nations. Today's Polish popular music is not different from the foreign one, even the Polish language is used less frequently.

${ }^{3}$ R. Sankowski, Polska krajem muzycznego obciachu. Co się stało z naszym popem? http:// wyborcza.pl/1,75475,16292879,Polska_krajem_muzycznego_obciachu_Co_sie_stalo_z.html, [access: 24.01.2016]. 
On such a music world a child builds its artistic value. Easy access to popular music makes it construct its artistic and aesthetic needs on these foundations. Therefore, it is important to the education through music to be justified by the real needs of a child, and not by the consequences of the "product" created by the media. Musical education is a field generating countless benefits in the personality, cognitive knowledge and social development of a child; it is natural and universal in reception. Unfortunately, the fact of music education being pushed out in the presence of widely accepted standards of media, puts the music pedagogy at the crossroads: to follow the contemporary trend, or to fight for the quality?

\section{Musical education and overall development of child}

In the following paragraph of the Article the results of various researches that show the influence of music and music education adequately focused on the comprehensive development of a child are presented. The author aims to note that music education focuses not only on developing musical aptitudes, talents and interests, but it can also affect other areas of art and science, as well as life in general.

Mirosław Kisiel ${ }^{4}$ in his studies presents the results, which show a strong association between music education and the development of voice, speech and language of child. This mainly concerns the musical activities based on singing. Learning music has a positive effect on the speech acquisition by a child; the correct accent and articulation. "Speech and music have their common source, one and the other is in fact a set of sounds". ${ }^{5} \mathrm{Kisiel}$, as well as many other music educators notes that singing as an extension of the speech is an additional way of expressing children's experiences, feelings and moods.

Beside the positive effect of music on the improvement of speech, its influence on the development of the nervous system is also noticeable. Brenda Hanna-Pladdy i Alicia MacKay in their article entitled The relations between instrumental musical activity and cognitive aging 6 present the results of studies conducted on seniors (60-83 years old), who learned music as children, as well as those who did not have such education. Studies have shown that

${ }_{4}^{4}$ M. Kisiel, Pedagogiczno-dydaktyczne aspekty wykorzystania muzyki w stymulacji rozwoju dziecka, Dąbrowa Górnicza 2007, p. 57-71.

5 W.A. Sacher, Pedagogika muzyki, p. 207.

${ }^{6} \mathrm{~B}$. Hanna-Pladdy, A. Mackay, The relations between instrumental musical activity and cognitive aging, Neuropsychology, 2011, 25(3), p. 378-386. 
people whose duration of learning music in childhood came to at least 10 years, were characterized by a much higher mental fitness compared with people who were not involved in that kind of education. The authors emphasized the importance of learning to play the instrument (regardless of the type of instrument), which promotes the development of brain plasticity and the emergence of additional neurons. The recently popular field of neurodidactics also indicates the impact of the musical activities on brain development, including the aforementioned neurogenesis, and on eliminating developmental disorders affecting the brain area. An example confirming that can be found in the article of Elżbieta Pędraszewska-Iskrzak ${ }^{7}$ showing, how the Shinichi Suzuki method of teaching music, can stimulate the development of a child with a multifactorial brain damage. The method based on learning to play the instrument resulted in a significant increase in language resources of the researched girl, even though the application of other activities has not produced any tangible results.

Subsequent research on the influence of music education on child relate to the development of abstract thinking. Karen C. Smith, Lola L. Cuddy and Rena Upitis ${ }^{8}$ notes that a child through learning to write and read music, through overcoming difficulties with recognizing differences between sounds and their duration, think musically, which definitely is a kind of abstract thinking.

In addition to singing and playing instruments, ${ }^{9}$ an important place in music education is occupied by music physical activity. It can be argued that this is the most natural form of musical education of a child. Popular in Poland Dalcroze Eurhythmics develops spatial and mobility coordination, engages the senses of sight and hearing, having a positive effect on the mastery of the whole body - muscles and nervous system. ${ }^{10}$ Movement to music, often proceeding as a way of entertainment, supports the development of memory, concentration and attention. ${ }^{11}$

7 E. Pędraszewska-Iskrzak, Stymulowanie rozwoju dziecka z wieloczynnikowym uszkodzeniem mózgu za pomoca metody Suzuki, [in:] Edukacja i/a mózg, mózg a/i edukacja, ed. M. Kowalski, I. Koszyk, S. Śliwa, Kraków 2016, p. 25-34.

${ }^{8}$ K.C. Smith, L.L. Cuddy, R. Upitis, Figural and metric understanding of rhythm, Psychology of Music, 1992, 22(2), p. 117-135.

${ }^{9}$ M. Forgeard et al., Practicing a Musical Instrument in Childhood is Associated with Enhanced Verbal Ability and Nonverbal Reasoning, PLoS One, 2008, 3(10), http://journals.plos.org/ plosone/article?id=10.1371/journal.pone.0003566, [access: 24.01.2016].

${ }^{10} \mathrm{~K}$. Krasoń, Ruch w przestrzeni. Kinestetyczne wspieranie rozwoju (analiza przypadku dziecka zahamowanego psychoruchowo), [in:] Sztuka w życiu i edukacji osób niepetnosprawnych. Wybrane zagadnienia, ed. E. Jutrzyna, Warszawa 2003, p. 179-191.

${ }^{11}$ J.A. Sloboda, B. Hermelin, N. O'Connor, An Exceptional Musical Memory, Music Perception, 1985, 3(2), p. 155-169. 
The fact that the growth of musical talent is influenced by a properly conducted music education is not surprising. A child surrounded and activated by music has the opportunity both to improve the skills and competencies of music, as well as to develop natural aptitudes and abilities in this area. However, an interesting finding is the way music education can affect the development of mathematical skills. The previously mentioned language skills seem to be quite obvious due to the use the same executive apparatus for the production of sound (speaking - singing). Meanwhile, the issue of mathematics is primarily based on the thinking and imagination. ${ }^{12}$ Anna Luczak $^{13}$ in the results of research cited examples of correlation between the subjects Math - Music, such as presentation of spatial relations on the plane, differentiation and naming of geometric shapes, comparing the differences between the lengths of sounds, ordinal numbers (timing, counting according to the measures, songs referring to mathematics) and fractions.

Apart from the activation and psychophysical development, it is stated that music education affects the formation of one's personality.

Musical activity of children, teenagers and adults in the system based on feedback relationship can form personality, understood as the brain structure arising in the course of action, and the traits of that personality will result initiating activity. ${ }^{14}$

Psychology of music and psychology of education are the main fields involved in studying the influence of music on a child. The scope of educational research involves the important for the child's development attitude of the teacher to the student in the activities referring to music education. Despite minimal research concerning these issues, observations and analysis reveal some facts:

- open attitude of the teacher during musical activities has a positive effect on the activation of the student,

- grading criticism and strengthening student motivation through of the verbal and non-verbal action can have a positive influence on student's selfesteem and self-confidence,

- creative attitude of the teacher enables the student's creative attitude to the issues of music.

12 C. Zhan, The Correlation Between Music and Math: A Neurobiology Perspective, http:// serendip.brynmawr.edu/exchange/node/1869, [access: 25.01.2015].

13 A. Łuczak, Między muzyka a matematyka. Wybrane zagadnienia z muzycznej edukacji wczesnoszkolnej, [in:] Treści, formy i metody przedmiotu "muzyka” w świetle reformy powszechnej edukacji: materiaty z ogólnopolskiej konferencji naukowej, ed. V. Przerembska, Łódź 2000, p. 47-61.

${ }^{14}$ M. Tyszkowa, Zdolności, osobowość i działalność uczniów, Warszawa 1990, p. 136. 
While analyzing the impact of music education on personality, the questions of aesthetic education in which musical training is included, cannot be ignored. According to the proponents of this trend, only education through art and to art enables the full development of student's personality. The pupil would base his aesthetic sensibility on progressive aesthetic perception acquired through his own creative activity. ${ }^{15}$

Emotionality is another area affected by music education. Emotions are an important area of the child's psyche in the educational and social process. It was observed that active musical activities benefit the feelings of joy, satisfaction and fulfilment. ${ }^{16}$ Another studies showed that classes based on the perception of music may shape the emotionality of older students, resulting in a lot of different feelings, i.e. sadness, excitement, calmness, joy, euphoria, anger. ${ }^{17}$

Music is also an excellent education field for developing the creative processes of a child. Working with sound allows the students to develop their imagination, which is of particular importance in terms of creativity. Creating new sound structures, spatial structures and sound and spatial structures triggers the previously inactive imaginative areas. Creativity developed through musical activity is something natural and uninhibited for a child and it is compatible with its internal needs.

Classes based on music are also an important element in the development of social attitudes of the student. Therefore, many of the actions of music education are directed to the social aspect of education. Music teachers note that collaborative music-making is an opportunity for the development of such attitudes as the ability to work, care for common success and satisfaction from achieving it in a group. It is important to mention that that children are keen to take part in extra-curricular musical activities. Their participation in such classes affects both the satisfaction of aesthetic needs and the need for participation in musical activities together in a group.

\section{The state of music education in Poland}

The basis for the analysis of the situation of music education in relation to other European countries is the report: Arts and Cultural Education at School in Europe published by the Education, Audiovisual and Culture Ex-

${ }_{15}$ M. Nowak, Wychowawcze wartości sztuki sakralnej, [in:] Sacrum - sztuka - wychowanie, ed. W.A. Sacher, Kraków 2006, p. 11-25.

${ }^{16}$ M. Kędzia, Radość z muzyki - praktyczne spojrzenie na edukację muzyczna w klasach I-III szkoty podstawowej, [in:] Filozofia i etyka w szkole. Edukacja artystyczna - wyzwania, ed. D.A. Michałowska, J. Ryczek, L. Suchanek, Poznań 2015, p. 225-231.

${ }_{17}$ N. Kłysz-Sokalska, Sztuka a wartość i przeżycie estetyczne, [in:] ibidem, p. 233-240. 
ecutive Agency. ${ }^{18}$ It shows that despite the fact that many actions are taken at the international level by UNESCO and even though there are activities of the European institutions such as the Council of Europe and the European Parliament, the position of artistic subjects in the curricula in Europe is still unsatisfactory and there is a high degree of variation in different EU countries.

A scarce amount of the aforementioned subject at schools has an adverse impact on the situation of music education in the Polish system. Poland is among the countries in which the number of hours of art classes is extremely low. For example: on the second stage of education (classes $4-6$ ) there are only 107 hours per year, while in Estonia it is 240 hours in Germany - 330, Austria - 510, Denmark - 670 and in Liechtenstein until - 902. This is the most important concern, because the lack of frequent contact with the music makes it impossible to achieve the objectives described in the previous paragraph of this article. One hour of music classes per week places the music in the group of the less important areas of children's activities. Music is not treated as a natural component of a general education or a means to acquire knowledge and skills, but merely an insignificant school subject.

In public schools not enough time is spent on the use of the talents and commitment of students in music. Despite the knowledge about the influence of music education on a lot of factors influencing a child, singing, playing instruments and movement with background music are rarely present in the schedule of the school day. Limited contact with music is also due the poor musical preparation of teachers. This applies mainly to the teachers of early education, where only one teacher is responsible for all the areas of science and arts, including music. The lack of basic teaching skills in the field of singing, playing instruments and moving to music does not allow the transfer of skills to the children, or involvement in musical activities together in a group. Teachers' fear of failure leads to the withdrawal of a child from all kinds of musical activity. A student of early school associates the music education only with the recording on the $\mathrm{CD}$. The teacher's level of personal music culture, which is based on the popular music provided by the media and the Internet, is also of great importance.

Positive aspect of current music education is its condition in kindergarten's education. This is influenced by Eurhythmics, which is present in the nursery schools and is the basic classes of music conducted by qualified professionals. The knowledge and skills possessed by Eurhythmics' teachers

18 EACEA, Arts and Cultural Education at School in Europe, http://eacea.ec.europa.eu/ education/eurydice/documents/thematic_reports/113en.pdf, [access: 25.01.2016]. 
influence the effectiveness of music education and the objectives concerning: the development of talents, interests, aesthetic needs, emotionality and socialization. Music education organised in a way that is compatible with the age of a child in preschool gives an excellent start to face challenges in school education. Properly conducted music training on the first stage of education could be one of the building blocks of the full personality of child. Hopefully, the current situation will change in favour of the musical education, and thus for the benefit of the student.

\section{BIBLIOGRAPHY}

EACEA, Arts and Cultural Education at School in Europe, http://eacea.ec.europa.eu/ education/eurydice/documents/thematic_reports/113en.pdf (access: 25.01.2016).

Forgeard M., Winner E., Norton A., Schlaug G., Practicing a Musical Instrument in Childhood is Associated with Enhanced Verbal Ability and Nonverbal Reasoning, „PLoS One”, 2008, $\mathrm{nr}$ 3(10), http://journals.plos.org/plosone/article?id=10.1371/journal.pone. 0003566, [access: 24.01.2016].

Hanna-Pladdy B., Mackay A., The relations between instrumental musical activity and cognitive aging, Neuropsychology, 2011, 25(3).

Kędzia M., Radość z muzyki - praktyczne spojrzenie na edukację muzyczną w klasach I-III szkoty podstawowej, [in:] Filozofia $i$ etyka w szkole. Edukacja artystyczna - wyzwania, ed. D.A. Michałowska, J. Ryczek, L. Suchanek, Wydawnictwo Naukowe Wydziału Nauk Społecznych, Poznań 2015.

Kisiel M., Pedagogiczno-dydaktyczne aspekty wykorzystania muzyki w stymulacji rozwoju dziecka, Wyższa Szkoła Biznesu w Dąbrowie Górniczej, Dąbrowa Górnicza 2007.

Kłysz-Sokalska N., Sztuka a wartość i przeżycie estetyczne, [in:] Filozofia i etyka w szkole. Edukacja artystyczna - wyzwania, red. D.A. Michałowska, J. Ryczek, L. Suchanek, Wydawnictwo Naukowe Wydziału Nauk Społecznych, Poznań 2015.

Kłysz-Sokalska N., Edukacja muzyczna kluczem do petnego rozwoju dziecka, [in:] Edukacja na rozdrożu. Część 3 - Dzieciństwo szans i zagrożeń, ed. R. Bernatova, S. Kania, S. Śliwa, Wydawnictwo Instytut Śląski, Opole 2016.

Krasoń K., Ruch w przestrzeni. Kinestetyczne wspieranie rozwoju (analiza przypadku dziecka zahamowanego psychoruchowo), [in:] Sztuka w życiu i edukacji osób niepetnosprawnych. Wybrane zagadnienia, ed. E. Jutrzyna, Akademia Pedagogiki Specjalnej im. Marii Grzegorzewskiej, Warszawa 2003.

Łuczak A., Między muzyka a matematyka. Wybrane zagadnienia z muzycznej edukacji wczesnoszkolnej, [in:] Treści, formy i metody przedmiotu „muzyka” w świetle reformy powszechnej edukacji: materiały z ogólnopolskiej konferencji naukowej, ed. V. Przerembska, Zakład Pedagogiki Muzycznej Uniwersytetu Łódzkiego, Łódź 2000.

Nowak M., Wychowawcze wartości sztuki sakralnej, [in:] Sacrum - sztuka - wychowanie, ed. W.A. Sacher, Oficyna Wydawnicza Impuls, Kraków 2006.

Pędraszewska-Iskrzak E., Stymulowanie rozwoju dziecka z wieloczynnikowym uszkodzeniem mózgu za pomoca metody Suzuki, [in:] Edukacja i/a mózg, mózg a/i edukacja, ed. M. Kowalski, I. Koszyk, S. Śliwa, Oficyna Wydawnicza Impuls, Kraków 2016. 
Sacher W.A., Pedagogika muzyki. Teoretyczne podstawy powszechnego kształcenia muzycznego, Oficyna Wydawnicza Impuls, Kraków 2012.

Sankowski R., Polska krajem muzycznego obciachu. Co się stato z naszym popem? http://wyborcza.pl/1,75475,16292879,Polska_krajem_muzycznego_obciachu_Co_si e_stalo_z.html, [access: 24.01.2016].

Sloboda J.A., Hermelin B., O'Connor N., An Exceptional Musical Memory, Music Perception, 1985, 3(2).

Smith K.C., Cuddy L.L., Upitis R., Figural and metric understanding of rhythm, Psychology of Music, 1992, 22(2).

Tyszkowa M., Zdolności, osobowość i działalność uczniów, PWN, Warszawa 1990.

Zhan C., The Correlation Between Music and Math: A Neurobiology Perspective, http://serendip.brynmawr.edu/exchange/node/1869, [access: 25.01.2015]. 